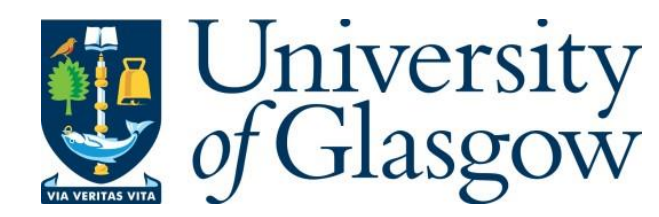

Dawson, M. (2017) Morality as rebellion: towards a partial reconciliation of Bauman and Durkheim. Distinktion: Journal of Social Theory, 18(3), pp. 255-273.

There may be differences between this version and the published version. You are advised to consult the publisher's version if you wish to cite from it.

http://eprints.gla.ac.uk/148089/

Deposited on: 15 September 2017

Enlighten - Research publications by members of the University of Glasgow

http://eprints.gla.ac.uk 


\title{
Morality as Rebellion: Towards a Partial Reconciliation of Bauman and
}

\section{Durkheim}

\author{
Matt Dawson, University of Glasgow
}

\begin{abstract}
This paper seeks to bring the sociologies on morality developed by Zygmunt Bauman and Émile Durkheim into conversation. Rather than adopting an approach which sees their perspectives as totally opposed it will be suggested that while there are differences in their broad approaches there is also a hitherto uncommented upon overlap concerning the possibility of moral rebellion. For Bauman, inspired by those who were part of the resistance to the Holocaust, this is seen to reside in the pre-social moral impulse to be for the other while Durkheim links this to the role of education as a form of moral socialisation. By exploring these links, we can see that both rely upon a conception of the conscience which, expressing the moral ideal lying behind our morally imperfect world, inspires actors to act morally in immoral times. The paper concludes by suggesting that this argument reflects recent claims concerning the potentially humanist elements of a sociological perspective and long-running debates on the potentially 'oversocialised' conception of individuals common to sociology. Therefore, this paper raises wider questions about the notion of the human resting behind sociological ideas.
\end{abstract}

Keywords Zygmunt Bauman, conscience, Émile Durkheim, humanist sociology, morality, rebellion; socialisation

For Anderson et al. (1985) sociology is an 'argument subject'. In putting forth this claim, the authors suggest one of the characteristics of sociology, along with some other social science subjects, is that rather than progress through the accumulation of rejected null hypotheses the discipline is home to a proliferation of different perspectives which tend to 'go round its problems time and again, achieving and rejecting resolutions of them, reviewing them, reformulating them, looking at them from different angles' (Anderson et al. 1958:53). For Anderson et al. (1985:55) this is not problematic, what is problematic is that many of these arguments have been unproductive. Rather than recognise that a plurality of perspectives can be useful, there has been a tendency to see one position as correct and all others as badly, perhaps even problematically, mistaken (Law 2014:1-12). I would suggest this is especially true in the field of social theory. Here, certain positions tend to fall in and out of favour in a process of 'turn-taking' (Law 2014:299). As part of this, the advocates of the victorious position may engage in 'theory-baiting' (Law 2014:8-10) in which the other side are 
portrayed as misguided enemies in a 'partisan, win-at-all costs ideological struggle' (Law 2014:9). While this can partly be explained by changing historical conditions, it can also result from the sometimes simplified visions of theoretical traditions which are passed down the generations.

This article moves away from such an approach by exploring a hitherto uncommented upon area of agreement between two theorists often seen as mortal enemies in the sociology of morality: Zygmunt Bauman and Émile Durkheim. It has increasingly become a truism to comment on how morality, so central a topic in the early years of the discipline, fell out of favour before enjoying its current renaissance (Shilling and Mellor 1998, Hitling and Vaisey 2010). In this 'return' to morality we have seen a variety of suggestions, including the importance of a cultural approach (Hitling and Vaisey 2010), the need to foreground 'lay normativity' (Sayer 2004), the requirement to be 'metaphysically agnostic' in the question of moral truth (Abend 2008) and the value to be gained from a Bourdieusian perspective (Igantow 2009, Pellandi-Simányi 2014). In the midst of this debate, in which many have written on both Bauman and Durkheim separately, one claim has been relatively consistent: their sociologies are mutually exclusive, whatever side one wishes to take in the argument (Shilling and Mellor 1998:195, Junge 2001:106 ff.) ${ }^{1}$. This is partly influenced by the somewhat simplistic image of Durkheim - namely the 'denigrator of the individual' who advocates the 'deification of society' (Bauman 2005:366) - Bauman and many of his commentators draw upon.

However, it is also true that there are indeed key areas in which Bauman disagrees with Durkheim and it would be difficult to reconcile their theories in totality. In this sense, it is not my goal in this paper to suggest Durkheim and Bauman's work on morality can be fully reconciled. Instead, I wish to claim that by choosing sides based upon the consensus of their mutual exclusivity, it is possible to overlook one area on which they are in some form of agreement. This concerns the potential for morality, in certain situations, to act as a form of rebellion against an immoral social formation.

As I will suggest in the conclusion - and in agreement with recent discussions concerning the humanist inheritance in sociology (Chernilo 2014, Durkin 2014, Morgan 2016) - being aware of this overlap also forces us to face up to what notion of the 'pre-social' human, to the extent such an idea is useful, sits behind the moral formations of sociologists This also returns us to earlier debates on the 'oversocialised' conceptions of individuals at the heart of some 
sociological explanations (Wrong 1961). Therefore, exploring this area of overlap raises larger questions about the notion of the human used in sociology, and the sociology of morality more specifically.

\section{Bauman's Sociology of Morality: Turning Durkheim on his Head}

I will begin with Bauman's sociology of morality. Bauman's contests what he takes to be a central proposition of sociology, from Durkheim onwards, that:

All morality comes from society; there is not moral life outside society; society is best understood as a morality-producing plant; society promotes morally regulated behaviour and marginalises, suppresses or prevents immorality...It is because the pre-social drives of the human animal are selfish, cruel and threatening that they have to be tamed and subdued if social life is to be sustained. Take away social coercion, and humans will relapse into the barbarity from which they had been but precariously lifted by the force of society (Bauman 1989:173)

This proposition, which Bauman argues was central to the Durkheimian and functionalist traditions, imagines immorality as a 'deviation from the norm' caused by 'unresolved managerial problems' for society. Durkheim's concern with the 'abnormal' state of anomie is taken to be an example of this (Bauman 1989:174-175).

Below we will turn to the question of how accurate a view of Durkheim this is. For now, what is significant is that Bauman see this as the dominant trend in sociology and therefore the point against which he wishes to argue. In doing so, he offers two main areas of disagreement. The first is that acceptance of such a view drastically curtails the ability for sociology to be critical. By 'deifying' society, Durkheim suggested that:

Man [sic, and throughout article] becomes humanised only when he surrenders to society...A statement 'this is a bad society' is inexpressible within Durkheimian logic; society may be inefficient, poorly organised... But, society cannot be bad; how could it be, if it is the only foundation, measure, and authority behind morality, the knowledge of good and evil...There is no detached, independent scale of values with which the morality sanctioned by a given society can be gauged and evaluated, and thus there is no logic in which the sentence "this society is bad' would make sense. Man, therefore, can be a moral being only as a result of his obedience to his society. Social conformity and humanity conflate (Bauman 1976:16) 
This, for Bauman, reduced sociology to the 'science of unfreedom', in which it is left solely to narrate, and thereby to deify, the limits to human action (Bauman 1976). The result is that sociology helps humanity as much 'as a painstaking description of the technology of making nooses helps the convict overcome his fear of the gallows' (Bauman 1978:193). Kilminster (2017) suggests this critique reflects Bauman's place within what he terms 'track I' of sociology's historical development. This, building upon the work of Marx and Engels, sees sociology as a form of 'social criticism' and engages in 'overcritique' as the condemnation of society. This perspective is fundamentally opposed to 'track II' sociology which, while containing both value-free and partisan positions, is more concerned with appreciating the historical development of society, along with its positives and negatives. Therefore, we can suggest, building upon Kilminster's argument, Bauman's dismissal of Durkheim on this point is primarily a political dismissal and reflects his being trained during a period in which the political conflict in sociology was between Marxist and structural functionalist perspectives, a period in which 'myths' about Durkheim were dominant (Giddens 1976). This is especially so when we consider Bauman's limited direct engagement with Durkheim's work, which I will discuss below.

The second disagreement for Bauman is an empirical one: the case of the Holocaust, which is foundational to the theoretical case he puts forward in his sociology of morality ${ }^{2}$. For Bauman, most sociologists who studied the Holocaust had embodied the Durkheimian position. These scholars had sought to understand the mechanisms by which people had been made to commit 'bad' acts, so that these could be adjusted to encourage 'good' acts. Or, they had sought statistical indicators for who was most likely to resist the Nazis (Bauman 1989:130). This had either been fruitless (there was no clear sociological indicator for who had been more likely to resist) or rested on the flawed assumption that somehow the Shoah was a deviation from the path of modern, morally deified societies. Rather 'it was the rational world of modern civilization that made the Holocaust thinkable' (Bauman 1989:13).

As is well known at this point, Bauman places a large amount of emphasis on bureaucracy as a sufficient condition for the Holocaust and its 'modernist' nature. As Bauman suggests, the 'traditional' forms of mass killing, such as the mob violence of Kristallnacht, proved to be ineffective as the main means for the Nazis to achieve their goal. So, an efficient form of organisation, ending in the Shoah, was required. Consequently, technical means were used to trace the 'success' of the Holocaust; reports come to be provided in terms of statistics which measure solely 'the progress of work, they say nothing about the nature of the operation or its 
objects' (Bauman 1989:99). This demonstrates the importance of reducing the moral requirement of bureaucratic action to questions of 'loyalty, duty, discipline' towards authority (Bauman 1989:160).

Before this was possible however, the concrete category of the Jewish person I know had to be turned into the abstract 'Jew'. As Bauman notes, while antisemitism was certainly present in Germany prior to the rise of the Nazis, it was not higher than elsewhere. This had been indicated by the negative reaction to early forms of street-based anti-Jewish violence, such as Kristallnacht. As Bauman (1989:189) argues, it was more effective to separate the 'Jew next door', who I know is a good person, from 'the Jew as such' who is deserving of my hatred by creating a separate legislative and social category of people. Consequently, the gradual disappearance of Jewish people from neighbourhoods did not raise much comment nor attempts to save those already seen as beyond contempt. Then, in the most challenging part of Modernity and the Holocaust, Bauman describes how Jewish people became 'part of the social arrangement which was to destroy them' through the implementation of the Judenrate in the ghettos (Bauman 1989:122). These councils drew up lists of Jewish people to be sent to the camps, encouraged Jews to work hard to show their worth to the Nazis and maintained order through their own Jewish police (Bauman 1989:117-150). On each step of the way rational, means-end calculative action replaced morality for both the Jewish people and other German citizens. Therefore, as Abend correctly puts it, Bauman's work, rather than, like most sociological accounts, being concerned with the social construction of morality is concerned with 'the social construction of immorality' (Abend 2008:103).

This empirical case then leads Bauman to construct a sociology of morality which rests upon the philosophy of Emmanuel Levinas (1985). This is Bauman's attempt to turn Durkheim on his head by conceiving of moral action as emerging not from societal instigations but rather from a moral impulse within the individual. Levinas' moral philosophy, based upon the notion of being 'for' the Other before one can be 'with' the Other, indicates 'the first reality of the self, a starting point rather than a product of society' (Bauman 1993:13). This being for the Other, experienced by recognising the 'face' of another individual, awakens my responsibility towards the other as someone worthy of my respect, love and care. The moral command, expressed most forcefully in the 'moral party of two', requires the agent to recognise the 'loneliness of the moral person' (Bauman 1993:61) as one who has only 'their own counsel and responsibility' (Bauman 2008:106) as a guide. How I respond to that moral command exists as a human challenge before the entry of socially mandated ethical codes. 
Consequently, for Bauman, philosophical and legislative quests for moral universalism have overlooked that the universal element of morality is the impulse of being for the other, rather than a set of moral principles (Bauman 1993) ${ }^{3}$.

Therefore, 'what societies do is manipulate morality rather than produce it' (Bauman and Tester 2001:54). This manipulation is achieved through two mechanisms: adiaphorisation and the structuring of choice. Adiaphorisation refers to removing certain forms of action from moral consideration. Such actions become 'neither good nor evil' but instead are solely 'measureable against technical (purpose-orientated or procedural) but not moral values' (Bauman 1991:144). This was, of course, most notable in the aforementioned cases of the Holocaust and the reduction of action to purely bureaucratic measures and language. However, for Bauman adiaphorisation is not a unique occurrence but rather is a 'necessary constitutive act' of 'all social organisation' (Bauman 1991:146). Consumer capitalism rests upon similar mechanisms of 'effacing the face' and 'casting the objects of action in a position from which they cannot challenge the actor in their capacity as a source of moral demands' (Bauman 1991:145), for example:

One cannot desire poverty for others without feeling morally contemptible; but one can desire lower taxes. One cannot desire the prolongation of African famine without hating oneself; but one can rejoice in falling commodity prices. What all such innocuous and technical sounding things do to people is not immediately visible. Neither are the people to whom they do it (Bauman 1988:93)

This is then linked to the prominence of choice in moral action. For Bauman, 'morality, after all (perhaps rather first of all) is about choice. No choice, no morality' (Bauman and Tester 2001:44) $)^{4}$ Responsibility for the other is fundamentally ambivalent; how we should fulfil it is not spelt out for us. Instead we face a selection of possible actions few of which are unambiguously good. Furthermore, even choices which seem good, if taken to the extreme, can be problematic. For example, the desire to care for someone, if taken too far, removes their autonomy (Bauman 1993:11). Also, as Todorov (1999:5) notes, acts of 'heroic' virtue, such as those found in the Warsaw Uprising, by refusing to concede defeat no matter the odds, can place one's comrades in danger. What is significant therefore is the structuring of choices. For Bauman, social reproduction rests upon some choices being made more probable than others (Bauman 1973:48). This operated in the Holocaust via creating conditions in which Jewish people choose to act in certain ways beneficial to the Nazis and in which the wider German population, aided by the process of adiaphorisation, choose not to help. The initial 
response from the reader may be to question whether this is actually a 'choice'. I will return to this question in the penultimate section of the paper.

There is an important implication from Bauman's sociology of morality. Namely, following Levinas, 'morality is before ontology' (Bauman 1993:71) in the sense of being before social existence and instead rests in the 'pre-social moral impulses common to humankind' (Bauman 1993:43). Perhaps unsurprisingly coming from a sociologist, this claim of a presocial moral impulse has been frequently criticised. For Junge (2001), what Bauman presented as an individual 'choice' is theorised as a universal 'obligation'. For others (e.g. Kaulingfreks 2005:44) this portrays a Rousseau-esque world in which actors are 'good' before they come to be manipulated by liquid modern society (Hookway and Ezzy 2017). There are three responses to this. Firstly, while it is true that Bauman speaks of morality, philosophically, as a 'pre-social' impulse such a distinction is impossible since humans do not exist outside a social situation. Indeed, denying any link with Rousseau, Bauman argues that if humans 'are something "intrinsically", they are social' (Bauman and Tester 2001:43); or, as he puts it elsewhere 'the non-social man lives nowhere but in social thought' (Bauman 1990:5). Philosophers (and social theorists) may draw upon the image of pre-social man for hermeneutical purposes, but an entirely 'pre-social' being has not, and cannot, exist. This is why Tester encourages us to think of Bauman's claim as not that morality is pre-social, but rather 'pre-societal', since it is independent of 'the external agencies and institutions that seek to manage and routinise togetherness' but only exists in the presence of an Other (Tester 2004:144). The concept of the 'societal' here then stands for the historically and culturally specific social norms, customs and institutions which shape our interaction and social being. While this is still largely a philosophical notion - just as there is no 'pre-social' being standing outside society, there is no 'pre-societal' being standing outside $a$ society - it gives us a clearer notion of where Bauman is placing the moral impulse; this distinction has hermeneutic value. In short, this impulse is imagined to be a universal impulse which is not subject to existing in a specific social figuration, though, as I will discuss below, it can be shaped by culturally and historically specific social norms, customs and institutions.

Secondly, given this, the claim of morality being 'before' ontology should not be taken as a temporal claim, but rather as positing a utopian ideal; to speak of morality being 'before being' means it exists 'in the realm-not-realm which is better than being' (Bauman 1993:75); the actions of our moral impulse would be 'better' than the morally imperfect worlds in which we live. Finally, given that we live in this morally imperfect social world it is neither 
the case that humans are essentially good or essentially bad, for Bauman they are simply 'morally ambivalent' (Bauman 1993:10). Humans inevitably experience the moral impulse, but this does not mean it leads to morally good actions. For example, a Jewish family's knock on the door with a request to shelter them during the Holocaust can be turned away on a rational basis, yet you can still experience shame in that decision (Bauman 1989:205).

As we have seen, Bauman's sociology of morality rests upon some notion of a moral impulse for the other. Philosophically pre-societal this comes to be manipulated by the forms of socially specific structured choices and adiaphorisation within which its owners act. However, thus far I have not discussed one of the key elements of Bauman's sociology of morality: the ability to make morally good choices in situations such as the Holocaust. It is precisely in this area, of morality as rebellion, that I see the hitherto uncommented overlaps between Bauman and Durkheim. Therefore, I will return to this after discussing Durkheim's sociology of morality.

\section{Durkheim's Sociology of Morality: Socialising Actors to be Moral Agents}

Contrary to Bauman's work, Durkheim's sociology of morality is well known and thus I will assume more background knowledge on the reader's behalf. However, one attribute of a theory being well known is that it may come to be understood in a simplified way. This can then aid the dismissal of theories as misguided turns. Such simplification, and sometimes outright misinterpretation, has especially been the case for Durkheim who, in Stedman Jones' (2001:x) words, is 'well known, but not known well'. Therefore, in what follows, I will not seek to outline Durkheim's sociology of morality in total but, rather, seek to emphasise how Durkheim saw individuals as socialised to be moral agents. This, significantly, is not a synonym for conformist agents. Such a view requires us to play especial attention to Durkheim's writings on education and philosophy and therefore to the 'old' Durkheim, regrettably dismissed now as 'residual' and only the 'beginning' of our understanding in contrast to the more fashionable 'new' cultural Durkheim (Smith and Alexander 2005:31).

As we shall see, this element of Durkheim's thought differs from the image of him presented by Bauman and those inspired by him. Although a vocal and frequent critique of Durkheim (see Bauman 2005) Bauman's actual engagement with Durkheim's writings is limited. For example, in Postmodern Ethics, while Durkheim is mentioned throughout the text as an image for Bauman to argue against, there are only two direct references to his work, both of which come from The Elementary Forms and focus solely on the distinction between 
'primitive' and 'modern' societies (Bauman 1993:133-135). Returning to the earlier point from Kilminster, we should understand Bauman's rejection of Durkheim as relying more on a perception of the general political principles of his sociology - gained by entering the field in a specific historical and political context - and their incompatibility with his view of critical sociology. This rejection has then been reproduced by Bauman's commentators, a good example being Beilharz who argues that 'there exists around Durkheim's work an aroma of conformism enough to make even the mildest mannered libertarian twitch' (Beilharz 2000:102). Even those more critical of Bauman praise his move away from a problematic 'Durkheimian normative ethics' (Hookway 2017:7). Notably, these claims also rest largely upon a certain image of Durkheim, rather than engagement with his writings. This reminds us, reflecting the introduction to this article, of the problems that can occur when we pursue simplified and unproductive arguments in the turn taking of social theory.

While Bauman's claim for a 'pre-social' morality has often been seen as problematic, there is also a clear pre-societal basis to Durkheim's sociology of morality, which resides in the 'constitutional duality of human nature'. Humanity conceives of itself as 'being formed of two radically heterogeneous beings: the body and the soul...the soul is invested with a dignity that has always been denied the body' (Durkheim 1973a:150-151). This duality of human nature is not simply a construction, since it reflects a real distinction - akin to his notion of non-transferrable human talent (Green 1989) - traced by Durkheim to the nature of morality:

Our intelligence, like our activity, presents two very different forms: on the one hand, are sensations and sensory tendencies; on the other, conceptual thought and moral activity. Each of these two parts of ourselves represents a separate pole of our being, and these two poles are not only distinct from one another but are opposed to one another (Durkheim 1973a:151)

Therefore, morality, linked to our soul, and our egoistic instincts, linked to our body, are engaged in a fundamental conflict ${ }^{5}$. For Durkheim, when the egoistic instincts win out we encounter the abnormal forms of social life. An example is anomie, which emerges in economic life when our desires, which form an 'insatiable and bottomless abyss' are not morally regulated (Durkheim 1952:207-219). Consequently, these egoistic instincts require an external authority to temper them which, representing the 'ideal' of morality (Durkheim 1920), operates as 'a moral power...whose superiority he recognises, and which cries out "You must go no further"” (Durkheim 1959:200). 
As is well known, Durkheim sees this moral power to rest with society, expressing itself via religion. As he puts it in The Elementary Forms, society 'requires us to become its servants, forgetting our own interests' (2001:154). This is achieved by the 'psychic energy' which 'makes us bend our will and incline to compliance' (Durkheim 2001:155). Society comes to represent and reflect the 'dignity' of the human soul (Durkheim 2001:159). Consequently:

the individual takes from society the best of himself, everything that gives him a distinct personality and a place among other beings, his intellectual and moral culture. Take away language, the sciences, the arts, and moral beliefs, and he falls to the level of brutishness. The characteristic attributes of human nature therefore come to us from society (Durkheim 2001:257)

Stop at this point of the discussion and the disagreements with Bauman are clear. Indeed, stopping at this point is exactly what the commentators who compare the two have often done (Crone 2008:67-68). Yet, this overlooks what Durkheim goes on to say in the above quote, namely that 'society exists and lives only in and through individuals' and therefore that 'society has reality only to the extent that it has a place in human consciousness, and we make this place for it' (Durkheim 2001:257). It is exactly this making 'a place' for society, achieved via education, to which we now turn.

As noted by Cladis (1995), Durkheim's writings on education, while seemingly concerned solely with the formal elements of schooling, actually have a broader interest with the socialisation of children. This is demonstrated by Durkheim's assertion (1956:71) that it is education which provides what he terms 'the essential conditions' of society's reproduction, fulfilling a role the family is no longer able to play. The explanation for this returns us to this duality of human nature:

Society finds itself with each new generation, faced with a tabula rasa, very nearly, on which it must build anew. To the egoistic and asocial being that has just been born it must, as rapidly as possible, add another, capable of leading a moral and social life. Such is the work of education, and you can readily see its great importance...It creates in man a new being (Durkheim 1956:72)

It is the need to bring out the elements linked to our soul, to create this new being of the moral agent, which defines the mission of education. While traditionally this could be achieved by a religious education, Durkheim argues contemporary society needed a form of 'moral education' which sought to provide the basis of a secular morality - one which 
grounds its precepts in universal ideas of humanity rather than specific religious commands guided by the state (Durkheim 1956, 1961).

Such an education has two important elements for this discussion ${ }^{7}$. Firstly, it seeks to inculcate some notion of duty. By bringing the child into a social setting beyond the family it seeks to develop the aforementioned individual consciousness through which society acts. This, for Durkheim shows how morality is not simply a 'schematic' set of principles, but rather exists 'through the relationships of associated individuals' (Durkheim 1961:86). Consequently, education should produce a 'voice that speaks to us, saying: this is your duty' when we are faced with a choice of action in cooperative social life (Durkheim 1961:89). This then links to the second element, discipline. As the preceding point indicates, Durkheim does not imagine moral education as some sort of rote learning of moral precepts. Undoubtedly, he does think attachment to these precepts are important, for example, he speaks of how the teacher, much like the priest in their relationship with God, should 'be attached to these ideals, let him feel all their grandeur, and the authority which is in them' (Durkheim 1956:89). However, when it comes to the actual child, what should be taught are 'the underlying reasons for the moral discipline he is asked to practice' (Durkheim 1909:130). Here Durkheim draws a distinction between the desire for no moral guidelines and 'the need to substitute a new [moral] regulation for an old one'; the former is impossible in a social situation where individuals associate subject to moral rules, the latter is a 'natural, healthy and fruitful' outcome of moral education (Durkheim 1961:53). In short, what moral education teaches is the discipline towards $a$ collective moral ideal not the currently existing one; or, in his terms, discipline towards 'those dispositions that prompt us to act morally, not in such and such a particular instance, but generally in men's relationship with one another' (Durkheim 1956:33).

For the purpose of our discussion, there are two key elements to take from Durkheim's discussion of moral socialisation. Firstly, that duty means developing individual consciousness awakened when faced with a moral choice. Secondly, the discipline which is engendered by this sense of duty means respect for and recognition of the need for some form of collective morality if not the one currently in existence. Both of these elements of Durkheim's work are central to his overlaps with Bauman on morality, to which I now turn.

Morality as Rebellion: Saying No in Order to Invoke a Higher Morality 
Durkheim saw the aforementioned need for moral discipline and the resulting sense of duty as especially pronounced for one major event in the life of an individual: the day on which 'partly of himself and partly under pressure for the environment, he will wonder by what right [existing forms of moral regulation] should be observed' (Durkheim 1909:130). It was inevitable that having developed individual consciousness, that same consciousness will question the basis on which it is called to act. Indeed, this is exactly what it must do:

A society like ours cannot, therefore, content itself with a complacent possession of moral results that have been handed down to it. It must go on to new conquests; it is necessary that the teacher prepare the children who are in his trust for those necessary advances. He must be on his guard against transmitting the moral gospel of our elders as a sort of closed book. On the contrary, he must excite in them a desire to add a few lines of their own, and give them the tools to satisfy this legitimate ambition (Durkheim 1961:13-14)

The goal is not to create a situation in which social actors blindly follow the gospel of what has been, but rather to create the conditions under which they can pursue moral acts even if they go against existing forms of moral regulation. This notion is missing in the Bauman-ian politically inspired interpretation of Durkheim in which the latter was seen to advocate 'an unswerving loyalty to the great and intelligent force of society' (Bauman 2005:372). Indeed, despite it being consistently overlooked in his writings, Durkheim is very clear that in certain situations disloyalty towards existing society is part of being moral:

We are not then obliged to bend our heads under the force of moral opinion. We can even in certain cases feel ourselves justified in rebelling against it...we shall feel it our duty to combat moral ideas that we know to be out of date and nothing more than survivals. The best way of doing this may appear to be the denial of these ideas, not only theoretically but also in action (Durkheim 1953:61)

This recognition that, to use Durkheim's term, we are justified in 'rebelling' against society's moral sanctions on occasion is somewhat obvious if one follows his writings and life. After all, he speaks explicitly in places of socialism seeking to introduce a 'higher morality' (Durkheim 1893:119) ${ }^{8}$. Furthermore, Durkheim's intervention in the Dreyfus affair encouraged people to remember that 'duty consists in disregarding all that concerns us personally...in order to seek out only that which our humanity requires and which we share with all our fellowmen' (Durkheim 1973b:45). 
What, then, creates the situation where agents are likely to engage in this form of rebellion? This rests in Durkheim's conception of individualism as a social and political principle. Here, however, we face somewhat of a contradiction. For Durkheim (1973b:54), individualism is 'socially instituted'. Our conception of the individual 'as a religion in which man is at once the worshipper and the god' (Durkheim 1973b:46) is one which exists in a particular social situation in which organic solidarity has reduced difference to the extent that the only common element is our 'humanity' (Durkheim 1973b:51). It was then on the basis of this conception of individualism - defined by a notion of the sovereign human - that Durkheim raises moral critiques about contemporary society, for example, with regards to inheritance which, in helping to produce 'injustice', is 'contrary to the spirit of individualism' (Durkheim 1991:213, 217). So, initially it seems we have Durkheim invoking the moral ideal of society (individualism) as a basis for rebelling against certain formations of that society (such as the injustice of inheritance or his actions combatting antisemitism in the Dreyfus affair). I will return to this seeming contradiction later on in the article. For now, what is significant is that Durkheim argues moral action can involve, to repeat the quote above, rebellion 'not only theoretically but also in action'.

This brings us to Bauman and his notion of morality operating through choice, which highlights the initial moral party of two and the obligation of recognising face. In such a situation, for Bauman, the possibility of choice expresses itself in either recognising the 'unconditional responsibility' or 'unspoken demand' the other invokes in me, or to deny it (Bauman 1998:15). If we are fortunate, this responsibility will chime with our socially sanctioned role (Bauman 1993:19). However, frequently it will conflict with it. In such a situation we can deny the face and follow norms, or accept the face and rebel against norms in defence of a moral ideal of the shared 'humanity' of individuals (Bauman 1998:15).

This was the case in the Holocaust. As Bauman notes, despite all the pressures upon them to act otherwise, to follow the commands of their socially sanctioned role, some did rebel and choose to aid the persecuted Jewish people. Drawing primarily, though not solely upon the research of Nechama Tec, Bauman highlights that such rebels could not be predicted by sociological characteristics (Bauman 1989:5) ${ }^{9}$. To explain this Bauman (1993:81) invokes the Levitasian notion of the 'Saint' as one who follows moral responsibility to its inevitable end in spite of societal pressure. If one lesson of the Holocaust is that most individuals when put in a position with few good choices will choose the one sure to guarantee selfpreservation, then the second lesson: 
tells us that putting self-preservation above moral duty is in no way predetermined, inevitable and inescapable. One can be pressed to do it, but one cannot be forced to do it, and thus one cannot really shift the responsibility for doing it on those who exerted the pressure. It does not matter how many people chose moral duty over the rationality of self-preservation - what does matter is that some did. Evil is not all-powerful. It can be resisted. The testimony of the few who did resist shatters the logic of self-preservation. It shows it for what it is in the end a choice (Bauman 1989:207)

This means, for Bauman, that being moral is fundamentally difficult: 'it is most certainly not a recipe for an easy and comfortable life' since 'all too often, morality...lies not in conforming to binding and well-nigh universally accepted and obeyed norms, but in staunch resistance to them - at enormous personal cost to the resistor' (Bauman and Lyon 2013:154). Saints, by their very definition, are rare. Despite its rarity it remains part of human praxis (Bauman 1973) as indicated by the presence in language of the "curious particle "no" which with its 'bizarre further tense, forces us to know without wishing it, that things may be different from what they are, that there is an alternative to every step taken or contemplated' (Bauman 1998:17). We ascribe the potential of moral rebellion into human culture - which provides the basis for social reproduction (Bauman 1973) - through language (Bauman 1998). It is on this point that Bauman draws a link to the work of Arendt (1977) arguing that her work highlighted the correct question in focusing on the 'moral responsibility for resisting' (Bauman 1989:177).

It is here that Bauman helps to solve the contradiction highlighted in Durkheim's work above. For both Bauman and Durkheim, moral rebellion rests upon some notion of the 'ideal', whether this be the pre-ontological moral ideal of Bauman or the socially shaped ideal of individualism for Durkheim. Despite these differences, for each, this ideal is temporally and socially specific. As Bauman notes, what is valuable about Levinas' perspective is that, even if we do not wish to accept it as an essential truth about humanity, it is well placed for a time of liquid modernity whereby 'being an individual (that is, being responsible for your choice of life, your choice among choices, and the consequences of the choices you chose)' is - thanks to increased marketisation, 'subsidiarisation' of responsibility to an individual level and the demand to control one's life trajectory - 'a decree of fate' (Bauman 2008:53). While the pressures of such a social conjuncture make the choice of the ethics of Nietzsche appealing, it is the ethics of Levinas, with its defence of the choice of being for the other which form the 'ideal' of such a time (Bauman 2008:93-124). Therefore, 
the everyday experience of liquid modernity emphasises the Levinasian choice in a similar way to which the more extreme fatal choice of the Holocaust did so; it is the ideal of liquid modernity.

For Durkheim, as we have seen, this ideal is specific to an era of organic solidarity and individualism. Therefore, drawing a comparison between 'traditional' morality and the ideals based around individualism, he suggests:

The principle of rebellion is the same as that of conformity. It is the true nature of society that is conformed to when the traditional morality is obeyed, and yet it is also the true nature of society which is being formed to when the same morality is flouted (Durkheim 1953:65)

By rejecting a particular form of morality, for Durkheim, rebellion always contains a notion of a different form of morality which it seeks to replace, as was the case, for example, for socialists (Durkheim 1953:64). Indeed, for Durkheim, an era in which moral thought remain unchallenged was an example of an immoral time since it gave up any notion of a moral ideal and simply accepted what is as inevitably 'good' (Durkheim 1920:81). Consequently, the value of individualism for some moral agents could have been seen to drive resistance to the Nazis, and would continue to inspire moral resistance today. In the work of both Bauman and Durkheim the moral ideal is historically and socially specific. Yet, we can assume that, as an 'ideal' it has not been empirically realised.

How, then, if it is not empirically realised in our moral relationships, is this ideal reproduced? For both, one entity is invoked to justify why certain individuals will follow this ideal and rebel: conscience. As Durkheim notes, even in times when a common morality is strong individual conscience will only 'almost' overlap with the collective form (Durkheim 2001:7) and instead 'each individual has, to a certain extent, his own morality' formed of their own 'inner moral life' and 'individual conscience' (Durkheim 1953:72). It is this individual conscience, complete with the socialisation of a moral agent which decides 'if there is reason to accept or reject' the moral currents of society (Durkheim 1956:150). Meanwhile, for Bauman, by resisting 'man is alone with his conscience, and only on its support can he count' (Bauman and Obirek 2015:30). Such a conscience is the element of morality which social forms of moral manipulation have, for Bauman, never been able to extinguish, given that they are always contested by some (Bauman 1993). 
Therefore, despite their other divergences, both Bauman and Durkheim leave a space open for morality operating as a form of rebellion against society. Both, in doing so, rely upon some conception of a moral ideal to which rebelling agents are driven by their conscience. Granted, this moral ideal is seen to emerge from different sources, but can also be seen as socially contingent and awakened in the inevitably social existence of humanity. An ideal will exist, but its exact form is contingent. This suggests a theory which while positing the existence of a 'conscience' which cannot be fully sociologically explained, also places this within key sociological concerns of socialisation and the contingent nature of moral laws. Our conscience, to use Durkheim's language, 'almost' matches the socially constructed moral norms under which we live. The difference in this match lies in how the conscience reflects the morally good ideal behind these norms, such as our shared humanity. Consequently, both Bauman and Durkheim leave a space open for moral actors to reject conformity in favour of rebellion.

To summarise, why do people morally rebel? Bauman's answer may guide us here:

We have little choice but to place our bet on that conscience which, however wan, alone can instil the responsibility for disobeying the command to do evil...Moral responsibility is the most personal and inalienable of human possessions, and the most precious of human rights. It cannot be taken away, shared, ceded, pawned, or deposited for safe keeping...This is, at least, what one can find out looking back at the protracted modern struggle to prove - to make real - the opposite (Bauman 1993:250)

We can find value here from a distinction drawn by Arendt (1977:231-233), based upon a quote by a German army physician, between 'morally meaningless' and 'practically useless' acts. As she notes, totalitarian regimes create ways for moral acts of resistance to go unrecorded. Rebels are not given a martyr's death, they simply 'disappear'. Therefore, potential rebels may recognise this as the ideal and see rebelling as the moral thing to do. But, these same actors may believe it will make no great difference in the long-run and therefore is practically useless and not worth doing. Nevertheless, as Arendt points out, such stories live on and gain meaning at a later date since, reflecting Bauman's conclusions, they remind us that 'under conditions of terror most people will comply but some people will not..."it could happen" in most places but it did not happen everywhere' (Arendt 1977:233). These stories demonstrate a conscience reflecting the ideal by which, morally, actors 'should' have acted. Sociologically, as I've explored in this article, these are important cases for understanding how morality works. Normatively, quoting Arendt once more, these stories of 
moral rebellion tell us that 'humanly speaking, no more is required, and no more can reasonably be asked, for this planet to remain a place fit for human habitation' (Arendt 1977:233). Such stories can give us hope and optimism concerning the future direction of humanity even if, repeating an earlier point from Bauman, we recognise they are difficult to replicate.

While this may prove a fitting conclusion to the space Bauman and Durkheim leave open for the conscience to play a role in moral rebellion, it also opens up a further question: by invoking this notion of a 'conscience' doesn't this argument return us to the problematic notion of the morally good, pre-social actor? I will now turn to this as part of the overall conclusions to be taken from my argument.

\section{Conclusion: Morality and the Oversocialised Conception of Individuals}

Writing primarily about the school of structural functionalism fashionable at the time Dennis Wrong (1961:192-193) argued:

I do not see how, at the level of theory, sociologists can fail to make assumptions about human nature. If our assumptions are left implicit, we will invariably presuppose of a view of man that is tailor-made to our special needs; when our sociological theory over-stresses the stability and integration of society we will end up imagining that man is the disembodied, conscience-driven, status-seeking phantom of current theory

Wrong was critical of what he saw as the 'oversocialised conception' of individuals in sociology, whereby all that it means to be an individual is developed via the internalisation of norms which are then reproduced by individuals eager for approval.

In a context more receptive to theories which seek to explain behaviour with reference to social position, Andrew Sayer (2004:3) suggested:

social scientists are prone to theory-practice contradictions, that is, to producing accounts of action which do not fit their own mundane behaviour, and which they could not themselves live. Thus, while the behaviour of others is explained in terms of social positioning and discourses - in effect, implying 'they would say/do that, wouldn't they', sociologists generally explain their own behaviour, like everyone else, by justifying it.

In this case, the critique of 'oversocialisation' could be said to apply to explanations which use social positioning as the only cause of social action, despite the fact sociologists would be reluctant to invoke such ideas personally. 
40 years apart and in different stages of the argument and turns of sociology, Wrong and Sayer highlight a consistent problem for sociology: explanations for social action which appear pre-social by invocating some innate 'human', or, in the case of this paper, a 'conscious'. For some, that this is seen as a problem indicates a fundamentally 'antihumanist' stream of thought which is common to a sociology reluctant to speak of the human subject (Durkin 2014, Morgan 2016).

As we have seen, it is this anti-humanist approach which Bauman, an undoubtedly humanist theorist, attempts to counter. Not only does Bauman invoke notions of the pre-social and a condition 'before ontology', he does so partly in order to claim a not wholly sociological outcome: resistance is not variable by social position and instead relies upon some notion of a 'moral saint' who feels they cannot do otherwise but chose to take a moral stand ${ }^{10}$. Indeed, Bauman's conception of moral action is akin to Todorov's (1999) notion of 'ordinary virtues'. Unlike heroic virtues, justified by the call to a greater good, such as the nation and a political ideology, performing acts of ordinary virtues 'doesn't lead anywhere at all, because it provides its own justification' (Todorov 1999:15). Awareness of the moral saint enacting ordinary virtues then, for Bauman, requires a different vocabulary for sociology; born of the same rationalised modernity which helped give birth to the Holocaust, sociology faces its own problems with "phrases like "the sanctity of human life" or "moral duty" which "sound as alien in a sociology seminar as they do in the smoke-free, sanitised rooms of a bureaucratic office' (Bauman 1989:29).

We might also suggest this focus on the moral 'saint' and the exceptional cases of moral resistance encourages sociologists to orientate their selection of cases more towards exceptional outliers. As Becker (2014:167-183) highlights, exceptional cases are mostly utilised in sociology as forms of 'killer questions' to disprove an interlocutor - those who say deviant acts are only those which are thus labelled face the response 'what about murder?' and those who claim the definition of 'art' is socially contingent are asked 'what about Mozart?'. However, the approach to morality sketched in this paper sees the moral saint not as a 'killer question' posed to sociologists of morality - 'what of Holocaust resisters? They were moral by rejecting their society's morality' - but rather as further cases to think with when considering what Todorov (1999:291), turning Arendt on her head, terms the 'banality of good'11. 
But while Bauman's humanist position would seemingly provide clear justification for his defence of some pre-societal moral agent engaged in saintly rebellion, Durkheim seems a much more difficult case. As Morgan (2016:24) notes, regardless of who we choose to include in the category of 'the classics', if Durkheim is in there he is probably the least humanist writer. As we have seen, Durkheim sees each new member of society as akin to a 'tabula rasa' who has to be trained with a sense of duty and discipline in order to 'arouse in us the sensation of perpetual dependence' (Durkheim 2001:154).

Yet, despite all that, Durkheim, like many humanists (Durkin 2014:207), was very happy to speak of 'humanity' as a subject we wish to know and as an attribute 'we share with our fellowmen' (Durkheim 1973b:45). Indeed, as we have seen, it is these kinds of attributes and the appeal to notions such as 'duty' and 'conscience' which left Durkheim open to the notion of morality in some way acting as a form of rebellion. This is perhaps unsurprising given that Durkheim did have some idea of human nature as existing 'prior' to our encounter with society (Durkheim 1973b). While this may be a pessimistic claim of a fundamentally egoist individual rather than Bauman's optimistic moral agent, it is still a pre-societal assertion. Therefore, following Wrong (1961), and more recently Chernilo (2014), Durkheim is part of the inevitable sociological tendency to make claims about human nature.

I would suggest that when it comes to the sociology of morality, such claims are especially inevitable. We live in morally imperfect times. In such a situation we need to reckon with the reproduction of immorality as much as morality, with evil as much as good. Consequently, some notion of how humans are driven to act will inevitably rest behind claims of why humans seek to pursue moral ends/disregard morality. Or, of why people may resist immorality and act morally; this implies a focus not solely on the social reproduction of morality, but also its disruption in search of a higher ideal. It would seem some sort of reductionist fantasy to claim that such disruptions can be solely predicted on the basis of societal positions. Indeed, a recent attempt to develop a Bourdieusian discussion of morality speaks of 'ethical capital' as something people gain from doing ethical acts (PellandiniSimányi 2014:668). While, of course, this can be valuable as a concept linked to symbolic recognition, as the author intends it, it limits the ability of sociology to attempt to explain moral outcomes. Its only contribution here would be the somewhat tautological reasoning that actors have ethical capital because they are (seen as) ethical. 
One possible way forward here is to follow Bauman and remember that 'the non-social man lives nowhere but in social thought' (Bauman 1990:5). In a view also shared by Durkheim, for whom 'man is man, in fact, only because he lives in society' (Durkheim 1956:76) ${ }^{12}$ this is a recognition that a concept of a 'pre-social' human makes sense only as a hermeneutic device for thinking about morality, rather than a direct empirical description. Therefore, as many humanists would note (Morgan 2016) any 'innate' attributes of humanity as a subject are only innate within society; this would potentially include some notion of a moral impulse which is 'innate' to a socialised morality, however this is activated. For Bauman, it is activated (and in turn extinguished) by moral 'proximity' whereas, for Durkheim, it is activated by forms of socialisation which bring the individual into contact with others beyond their immediate circle and into some invocation of duty and discipline. This requires a moral ideal which is socially contingent, but not equated with conformity; it is difficult to conceive of conscience without this ideal. In each case, this opens up the possibility for the moral impulse expressed in our conscience to act otherwise, to be moral in times when immorality is the common outcome.

\section{Acknowledgements}

I would like to give a special acknowledgement to the three reviewers on this article. All three provided reviews which were detailed, useful and constructively critical. Not only this, but their reviews were returned in just over a month. They were testaments to how the peerreview system is supposed to work. My thanks also in this regard to Christian Borch, the editor-in-chief of Distinktion, for facilitating such a rewarding review process. Finally, thanks to Kieran Durkin for reading a draft version of this article.

1. One exception to this is Abend (2008), who, in his separation of Weberian and Durkheimian approaches to morality places Bauman in the latter category. However, Abend's discussion concerns questions of truth and normativity, on which Bauman is closer to Durkheim, rather than the sources of morality, on which he is seen to disagree.

2. As I have discussed elsewhere (Dawson 2012) it is difficult to underestimate the significance of the empirical case to the Holocaust to Bauman's theoretical argument concerning morality in post/liquid modernity. As we shall see below, this is most noteworthy when it comes to the case of those who resisted the Nazis. 
3. This has led to one of the most common criticisms against Bauman, expressed forcefully by Sayer (2004:17-18), that, despite what Bauman claims, there never was a universal moral code under modernity. However, this criticism overlooks that Bauman claims such universal codes never existed at an empirical level. Instead, the search for them was a 'philosopher's worry' (Bauman 1993:38); of concern for those seeking to impose logic on the world, and the state actors who sought their assistance, but of less significance to lay actors who would go about their daily life drawing moral inspiration from a variety of sources (Bauman 1993:37-39). As an aside, Durkheim is also critical of the tendency to imagine there can be a universal code contemplated by actors. While philosophers might seek this its result would for 'morality to become a thing of vanity and luxury' since 'the vast majority of men carry out moral imperatives passively and the more cultivated men only partially reflect upon them' (Durkheim 1908:61).

4. All emphasis in quotes is the author's own.

5. This split of the 'soul' and 'body' may strike the contemporary reader as questionable. See Schilling and Mellor (1998) for a discussion of this element of Durkheim's work.

6. As noted earlier, while some have drawn (contestable) links between Bauman's theory of morality and that of Rousseau, a clearer point of comparison for Durkheim is Freud, especially when we account for these 'insatiable' desires which must be repressed. Indeed, for Ferguson (1996:199-206) a combination of Durkheim and Freud provides a useful sociological and psychological explanation for the "regulated de-regulation of desires... which provide the essential "physical-energy" for the perpetual expansion of consumption' in the postmodern age (Ferguson 1999:206). While I do not have the space to explore these links further, for the purpose of this paper Freud and Durkheim have both overlaps and disagreements on the questions of moral rebellion. While Freud leaves open the possibility that 'revolts' against forms of injustice can seek to further existing civilization - perhaps matching the notion of fulfilling the Durkheimian notion of the 'ideal'- he also suggests its comes from an 'original personality, still untamed by civilization', which seeks individual satisfaction by the overthrow of civilization (Freud 1930:42). This is a fundamentally un-Durkheimian notion

7. There is a third element of moral education, integral to Durkheim's sociological alternative, which rests upon education's ability to develop the 'spirit of association' which is central to his advocacy of professional corporations (Durkheim 1961:235). This discussion is beyond the scope of this article (see Dawson 2016).

8. This reference to socialism opens up a wider question concerning the long-running debate on Durkheim's politics. I do not have the space to discuss this fully here, but elsewhere I have discussed why we should think of Durkheim as a fundamentally socialist, rather than conservative or liberal, thinker (Dawson 2013). 
9. Despite, in what can be considered as somewhat of a rarity in Bauman's late intellectual career, this point being backed up with reference to empirical research, sociologists still seem somewhat reluctant to accept it. For example, Sayer (2004:18) suggests that resisting was 'nothing other than the ordinary empirical responsiveness to the suffering and flourishing of others'. This leaves unanswered that if such responsiveness was 'ordinary' why was resistance to the Nazis so exceptional? Or, vice versa, if pressures to conform were so strong, in this case literally life or death, why didn't everyone do so?

10. The invocation of Martin Luther here is deliberate, see Bauman and Obirek (2015:37-52).

11. I am thankful to one of the reviewers for providing this point about the exceptional nature of the moral saint case. I take full responsibility/blame however, for the application of Becker's work here.

12. We should also be wary of the use of the masculine pronoun here. As discussed by both Irigaray (1991) and Ahmed (2000:114-133) Levitas' ethical philosophy tends to a disembodied, unsexed other. This in turn underplays the fact that 'the other' is experienced as an embodied entity who we love (or do not). Hookway (2017) has suggested these critiques apply equally to Bauman (who Ahmed mentions en passant in her discussion). While an important avenue of critique, this can underplay the emphasis Bauman places on proximity for moral action, on the way in which the social manipulation of morality partly relies upon removing the embodied other from my physical position (see Bauman 1990).

\section{$\underline{\text { References }}$}

Abend, Gabriel (2008) 'Two Main Problems in the Sociology of Morality', Theory \& Society, 37(1): $87-125$.

Ahmed, Sara (2000) Strange Encounters: Embodied Others in Post-Coloniality London: Routledge.

Anderson, Robert J. Hughes, John A. and Sharrock, Wesley W. (1985) The Sociology Game: An Introduction to Sociological Reasoning, London: Longman.

Arendt, Hannah (1977) Eichmann in Jerusalem: A Report on the Banality of Evil, London: Penguin.

Bauman, Zygmunt (1976) Towards a Critical Sociology: An Essay on Commonsense and Emancipation, London: Routledge. 
Bauman, Zygmunt (1978) Hermeneutics and Social Science: Approaches to Understanding, London: Routledge.

Bauman, Zygmunt (1988) Freedom, Milton Keynes: Open University Press.

Bauman, Zygmunt (1989) Modernity and the Holocaust, Cambridge: Polity.

Bauman, Zygmunt (1990) 'Effacing the Face: on the Social Management of Moral Proximity', Theory, Culture \& Society, 7(1): 5-38.

Bauman, Zygmunt (1991) 'The Social Manipulation of Morality: Moralizing Actors, Adiaphorizing Action', Theory, Culture \& Society, 8(1): 137-51.

Bauman, Zygmunt (1993) Postmodern Ethics, Cambridge: Polity.

Bauman, Zygmunt (1998) 'What Prospect of Morality in Times of Uncertainty?', Theory, Culture \& Society, 15(1): 11-22.

Bauman, Zygmunt (2005) 'Durkheim's Society Revisited' in Jeffrey C. Alexander and Philip Smith (eds) Cambridge Companion to Durkheim, Cambridge: Cambridge University Press, 360-83.

Bauman, Zygmunt (2008) The Art of Life, Cambridge: Polity.

Bauman, Zygmunt and Lyon, David (2013) Liquid Surveillance, Cambridge: Polity.

Bauman, Zygmunt and Obirek, Stanislaw (2015) On the World and Ourselves, Cambridge: Polity.

Bauman, Zygmunt and Tester, Keith (2001) Conversations with Zygmunt Bauman, Cambridge: Polity.

Becker, Howard (2014) What about Mozart? What about Murder? Reasoning from Cases, Chicago: University of Chicago Press.

Beilharz, Pere (2000) Zygmunt Bauman: Dialectic of Modernity, London: Sage.

Chernilo, Daniel (2014) 'The Idea of Philosophical Sociology', British Journal of Sociology, 65(2): $338-57$ 
Cladis, Mark (1995) 'Education, Virtue and Democracy in the work of Emile Durkheim', Journal of Moral Education, 24(1): 37-52.

Crone, Manni (2008) 'Bauman on Ethics - Intimate Ethics for a Global World?' in Michael Hviid Jacobsen and Poul Poder (eds) The Sociology of Zygmunt Bauman: Challenges and Critique, Aldershot: Ashgate, 59-74.

Dawson, Matt (2012) 'Optimism and Agency in the Sociology of Zygmunt Bauman', European Journal of Social Theory, 15(4): 554-569.

Dawson, Matt (2013) 'Autonomous Producers of the World Unite, You Have Nothing to Lose but Your Economic Anomie! Émile Durkheim's Libertarian Socialist Critique', Critical Sociology, 39(5): 689-704.

Dawson, Matt (2016) Social Theory for Alternative Societies. London: Palgrave Macmillan.

Durkheim, Émile (1893) 'Belot and Socialism' in Émile Durkheim Durkheim on Politics and the State, Stanford: Stanford University Press, 113-20.

Durkheim, Émile (1908) 'A Discussion on Positive Morality: The Issue of Rationality in Ethics' in Émile Durkheim Durkheim: Essays on Morals and Education, London: Routledge \& Kegan Paul, 52-64

Durkheim, Émile (1909) 'A Discussion on the Effectiveness of Moral Doctrines' in Émile Durkheim Durkheim: Essays on Morals and Education, London: Routledge \& Kegan Paul, 129-39.

Durkheim, Émile (1920) 'Introduction to Ethics' in Émile Durkheim Durkheim: Essays on Morals and Education, London: Routledge \& Kegan Paul, 77-96.

Durkheim, Émile (1952) Suicide, London: Routledge.

Durkheim, Émile (1956) Education and Sociology, New York: Free Press.

Durkheim, Émile (1959) Socialism and Saint-Simon, London: Routledge.

Durkheim, Émile (1961) Moral Education: A Study in the Theory \& Application of the Sociology of Education, New York: Free Press. 
Durkheim, Émile (1973a) 'The Dualism of Human Nature and its Social Conditions' in Émile Durkheim On Morality and Society, Chicago: University of Chicago Press, pp. 149-63.

Durkheim, Émile (1973b) 'Individualism and the Intellectuals' in Émile Durkheim On Morality and Society, Chicago: University of Chicago Press, 43-57.

Durkheim, Émile (1991) Professional Ethics and Civic Morals, London: Routledge.

Durkheim, Émile (2001) The Elementary Forms of Religious Life, Oxford: Oxford University Press.

Durkin, Kieran (2014) The Radical Humanism of Erich Fromm, Hampshire: Palgrave Macmillan.

Ferguson, Harvie (1999) The Lure of Dreams: Sigmund Freud and the Construction of Modernity. London: Routledge.

Freud, Sigmund (1930) Civilization and its Discontents. London: Penguin.

Giddens, Anthony (1972) 'Four Myths in the History of Social Thought', Economy and Society, 1(4): 357-385.

Green, Simon J.D. (1989) 'Émile Durkheim on Human Talents and Two Traditions of Social Justice', British Journal of Sociology, 40(1): 97-117.

Hitlin, Steven and Vaisey, Stephen (2010) 'Back to the Future: Reviving the Sociology of Morality' in Steven Hitlin and Stephen Vaisey (eds) Handbook of the Sociology of Morality, London: Springer, 3-14.

Hookway, Nicholas (2017) 'Zygmunt Bauman's Moral Saint: Reclaiming Self in the Sociology of Morality', Acta Sociologica, published online first, DOI: $10.1177 / 0001699316688947$.

Hookway, Nicholas and Ezzy, Douglas (2017) 'Aesthetic and Relational Ethics: Beyond Bauman's Postmodern Ethics' in Michel Hviid Jacobsen (ed.) Beyond Bauman: Critical Engagement and Creative Excursions, London: Routledge, 29-45.

Ignatow, Gabriel (2009) 'Why the Sociology of Morality Needs Bourdieu's Habitus', Sociological Inquiry, 79(1): 98-114. 
Irigaray, Luce (1991) 'Questions to Emmanuel Levinas' in Margaret Whitford (ed.) The Irigaray Reader Oxford: Blackwell, 178-189.

Junge, Matthias (2001) 'Zygmunt Bauman's Poisoned Gift of Morality', British Journal of Sociology, 52(1): 105-19.

Kaulingfreks, Ruud (2005) 'Are we all Good? Zygmunt Bauman's Response to Hobbes', Sociological Review, 53(S1): 30-45.

Kilminster, Richard (2017) 'Overcritique and Ambiguity in Zygmunt Bauman's Sociology: A Long-Term Perspective' in Michel Hviid Jacobsen (ed.) Beyond Bauman: Critical Engagement and Creative Excursions, London: Routledge, 201-223.

Law, Alex (2014) Social Theory for Today: Making Sense of Social Worlds, London: Sage.

Levinas, Emmanuel (1985) Ethics and Infinity: Conversations with Phillippe Nemo, Pittsburgh: Duquesne University Press.

Morgan, Marcus (2016) Pragmatic Humanism: On the Nature and Value of Sociological Knowledge, London: Routledge.

Pellandini-Simányi, Léna (2014) 'Bourdieu, Ethics and Symbolic Power', The Sociological Review, 62(4): 651-74.

Sayer, Andrew (2004) 'Restoring the Moral Dimension: Acknowledging Lay Normativity', published by the Department of Sociology, Lancaster University. Available at http://www.lancaster.ac.uk/fass/resources/sociology-online-papers/papers/sayer-restoringmoral-dimension.pdf

Shilling, Chris and Mellor, Philip (1998) 'Durkheim, Morality and Modernity: Collective Effervescence, Homo Duplex and the Sources of Moral Action', British Journal of Sociology, 49(2): 193-209.

Smith, Philip and Alexander, Jeffrey C. (2005) 'Introduction: the New Durkheim' in Jeffrey C. Alexander and Philip Smith (eds) Cambridge Companion to Durkheim, Cambridge: Cambridge University Press, 1-37.

Stedman Jones, Susan (2001) Durkheim Reconsidered, Cambridge: Polity. 
Tester, Keith (2004) The Social Thought of Zygmunt Bauman, Hampshire: Palgrave Macmillan.

Todorov, Tzvetan (1999) Facing the Extreme: Moral Life in the Concentration Camps, London: Weidenfeld and Nicolson.

Wrong, Dennis (1961) 'The Oversocialised Conception of Man in Modern Sociology', American Sociological Review, 26(2): 183-93.

Matt Dawson is a Lecturer in Sociology at the University of Glasgow with research interests in social theory, political sociology and the history of sociology. He is the author of Social Theory for Alternative Societies (2016, Palgrave Macmillan) and Late Modernity, Individualization and Socialism: An Associational Critique of Neoliberalism (2013, Palgrave Macmillan) as well as co-editor of Stretching the Sociological Imagination: Essays in Honour of John Eldridge (2015, Palgrave Macmillan). 